Short note

\author{
L. Sánchez Villegas, E. Sánchez Gullón \& A. F. Muñoz Rodríguez
}

\title{
Some interesting species to the flora of Huelva and Sevilla (SW Spain)
}

\begin{abstract}
Sánchez Villegas, L., Sánchez Gullón, E. \& Muñoz Rodríguez, A. F.: Some interesting species to the flora of Huelva and Sevilla (SW Spain). — Fl. Medit. 29: 103-108. 2019. — ISSN: 11204052 printed, 2240-4538 online.

Six new records of interesting vascular plants are described for the provinces of Huelva and Sevilla (Spain). For each taxon, details are given of distribution, habitat, ecology, previous records and the extent of naturalization for the alien species. In addition, a new spontaneous hybrid species is described in the Linaria Mill. (Scrophulariaceae) genus: Linaria $\times$ erebea Sánchez Gullón \& Muñoz Rodr., located in the province of Huelva.
\end{abstract}

Key words: floristics, Iberian Peninsula, xenophytes.

\section{Introduction}

Six new records of interesting vascular plants are described for the provinces of Huelva and Sevilla (Spain). These floristic novelties here presente are mainly the result of fielwork of first autor in Huelva and Sevilla (SW Iberian Peninsula) between 2016 and 2018. Voucher specimens of all taxa preserved in the herbaria of the University of Sevilla (SEV) and the Royal Botanical Garden of Madrid (MA).

\section{Results}

Allium pruinatum Link ex Spreng., Syst. Veg. 2: 35 (1825) (Liliaceae)

Huelva: Almonte, Estación Biológica Doñana, proximidades Laguna Santa Olalla 29SQA2397. 11/7/2018. L. Sánchez Villegas \& E. Sánchez Gullón (SEV 287455).

Iberian endemism present in central and southern Portugal and western Andalusia (Pastor \& Valdés 1983; Aedo 2013). In the village of Almonte, it has been found in sandy soil in pinewoods, outside the Doñana Natural Area (Garrido \& al. 2002), making this the first reference for this geophyte within the Doñana Biological Reserve. It is located on the edges of a firebreak close to the Santa Olalla lagoon. This is a taxon classified by the UICN as DD (Magos \& Kell 2011) and described as D1 Vulnerable (VU) in the Red List of 
Spanish Vascular Flora (Moreno 2008); it is also mentioned in Decreto 23/2012, 14 February, which regulates the conservation and sustainable use of indigenous flora and fauna and their habitats in Andalusia.

Astragalus sesameus L., Sp. Pl. 2 (1753) (Leguminosae)

Huelva: Huelva, La Orden, en herbazal sobre suelos básicos con restos conchíferos 29SPB8368. 15/5/2016. E. Sánchez Gullón (SEV286624).

Therophyte found in dry pastures, the edges of pathways and crops, and preferably calcicolous (Rivas Goday, 1953). Endemic to the western Mediterranean, it is frequently found in the east of the Iberian Peninsula, and is rarer in western Andalusia where it has been cited in Cádiz, Córdoba and Sevilla (Vicioso 1948; Pujadas 1986; Almeida 2003; Podlech 2000). The record presented here is new for the province of Huelva, where it has never previously been cited. The habitat where it was located has limestone soil of the Huelva Sands formation (Civis \& al. 1987), with silt containing numerous conchifera remains, in particular bivalves, gastropods and scaphopods from the Cenozoic era.

Lythrum portula (L. ) D. A. Webb, Feddes Repert. 71: 13 (1967) (Lythraceae)

Sevilla: Almadén de la Plata, orilla Rivera del Cala, 29SQB5285. 6/7/2018. L. Sánchez Villegas \& E. Sánchez Gullón (SEV 287457).

Aquatic terophyte widely distributed across the Iberian Peninsula, which Velayos (1997) cited in the western Andalusian provinces of Córdoba, Cádiz and Huelva. Subsequently, Morales \& al. (1998) located it in the village of Constantina, in the Sierra Norte, in the province of Sevilla. The location is confirmation of its presence in this province, having been discovered in pteridophyte pastures temporarily flooded by the river course.

Solanum sisymbryfolium Lam., Tab. Encycl. 2: 25 (1794) (Solanaceae)

Huelva: Rociana del Condado, cuneta camino agrícola junto alcornocal psammófilo, 29SQB1030. 15/9/2018. E. Sánchez Gullón (SEV287456).

South American xenophyte, which is known from valleys in Cantabria and the Atlantic valleys of the Basque Country and Pontevedra (Sobrino Vesperinas \& Sanz Elorza 2012), has been cited on the coast of Huelva where it appears in industrial zones around the port area (Sánchez Gullón 2000), which matches the findings of Gómez Vigide \& al. (2006) who postulated its possible appearance via commercial traffic. The record presented here confirms its possible naturalization in the province of Huelva.

Teucrium pseudocamaepitys L., Sp. Pl. 562 (1753) (Lamiaceae)

Huelva: Ayamonte, en protosuelo calizo, 29SPB4122. 13/4/2013. L. Sánchez Villegas \& E. Sánchez Gullón (MA926168).

This taxon is known in the central, southern and eastern Iberian Peninsula, and has been cited in Cádiz, Córdoba and Sevilla, in western Andalusia (Navarro 2012). This is the first 
reference to it in the province of Huelva; it appears in limestone soils close to the Parador, and is associated to other calcicolous species of interest for their rarity in Huelva, such as Picris willkommii (Sch. Bib.) Nyman, Centaurea bombycina Boiss., etc.

Gratiola officinalis L., Sp. P1. 17 (1753) (Scrophulariaceae)

Sevilla: Almadén de la Plata, orillas de la Rivera del Cala 29SQB5285. 6/7/2018. L. Sánchez Villegas \& E. Sánchez Gullón (SEV287458).

This species is dispersed across the centre, west and northeast of the Iberian Peninsula. Romero (2009) cites it in western Andalusia but only in Córdoba, although it had previously been cited in Sevilla, around the village of El Ronquillo (Pina 2000). It has recently been detected at the head of the Cala stream, in the municipality of Almadén de la Plata, which confirms its presence in the province of Sevilla, in the natural region of the Sierra Norte, where it appears associated to Gratiola linifolia Vahl, forming mixed hygrophila grasslands.

Linaria ×erebea Sánchez Gullón \& Muñoz Rodr. nototaxon nov. (Figura 1B). (Scrophulariaceae)

[Linaria incarnata (Vent.) Spreng. $\times$ L. spartea (L.) Willd.]

A new natural hybrid of the Linaria Mill. genus is described, formed between the parental Linaria incarnata (Vent.) Spreng. (Figure 1A) and L. spartea (L.) Willd. (Figure 1C), belonging to Subsect. Versicolores Benth., both distributed among pastures and scrubland clearings on sandy substrata in the west of the peninsula (Sáez \& Bernal 2009). This new hybrid it appears in sandy soils along the coast and in the river Odiel basin at the Andévalo.

Holotypus: Huelva: Marismas del Odiel, en suelo arenoso ácido 29SPB8025. 15/5/2017. E. Sánchez Gullón (MA926163) (Fig. 1).

Description: Hybrid plant with intermediate morphological characters between both parents. Stem with unicellular non-glandular and multicellular glandular hairs. Corolla with pale coloration, from yellowish to lilac; with oblique spur. Capsules intermediate in size between its parents.

Etymology: The nothospecific name Erebea refers to "Palus Erebea" -Infernal Lagoon-, a Greek name used by the Romans when referring to the mouth of the Odiel river.

Habitats: It inhabits grasslands in sandy soils, among its parents.

Distribution area: In the litoral and Andévalo regions, province of Huelva (SW Spain).

Diagnosis: Linaria incarnata presents multicellular glanduliferous hairs, and L. spartea has non-glanduliferous unicellular hairs. The hybrid presents both types of hairs, and its glanduliferous hairs are longer than those of L. incarnata. L. incarnata has violet flo- 
Sánchez Villegas \& al.: Some interesting species to the flora of Huelva and ...

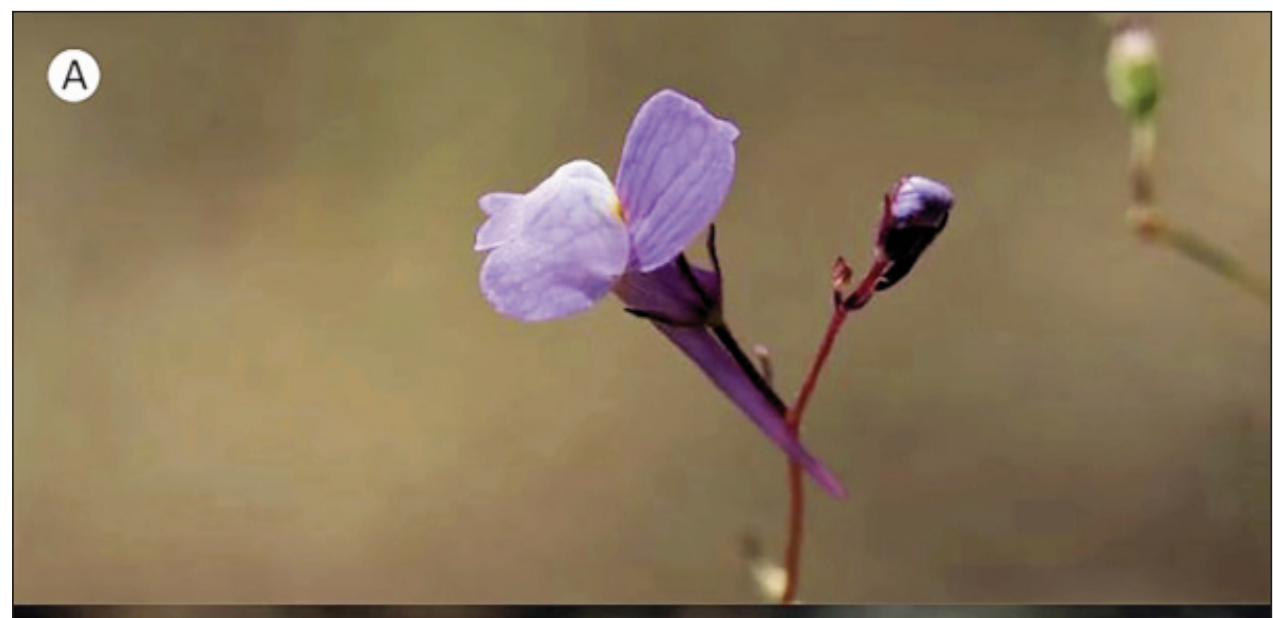

B

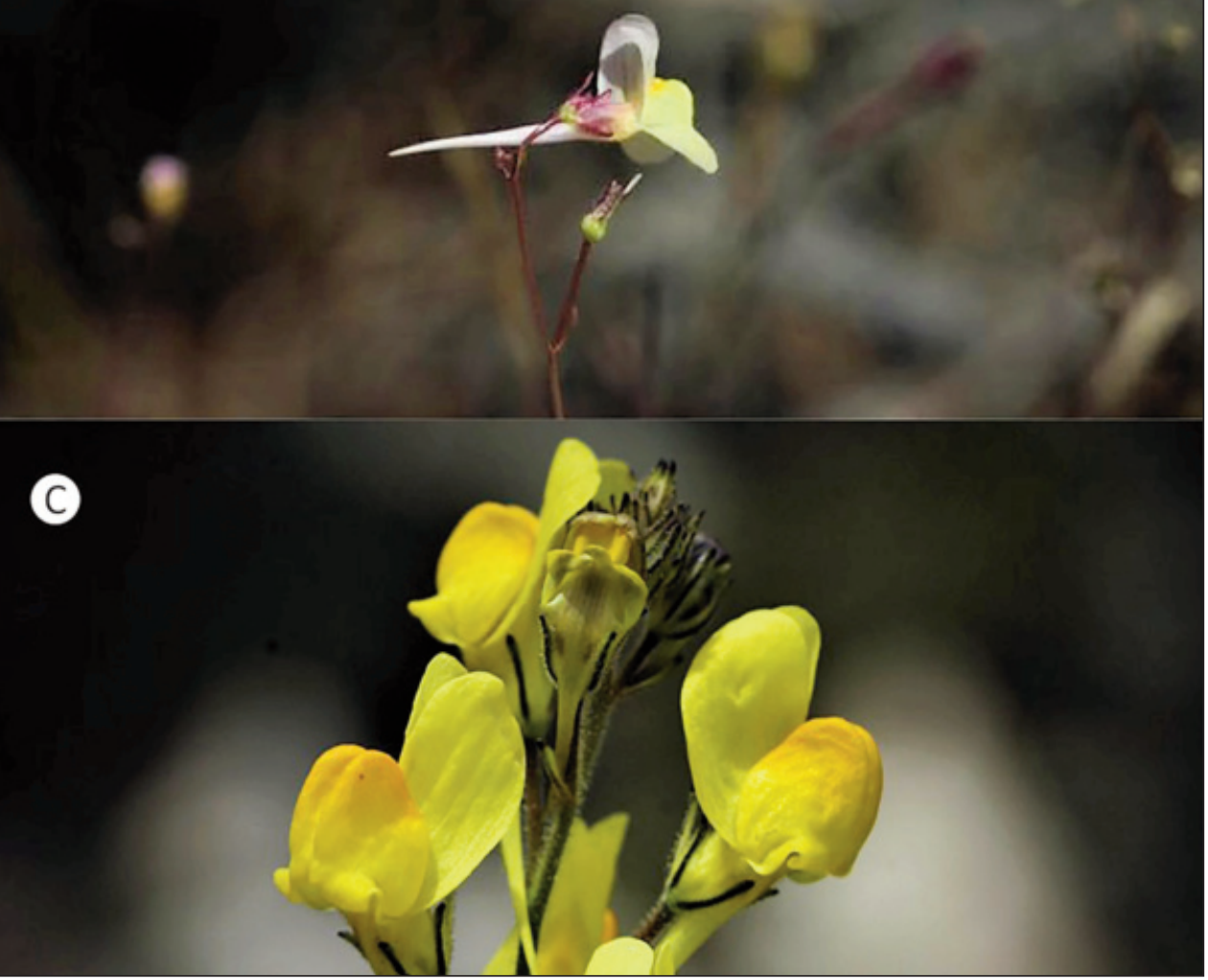

Fig. 1. A) Linaria incarnata (Vent.) Spreng.; B) Linaria × erebea Sánchez Gullón \& Muñoz Rodr.; C) Linaria spartea (L.) Willd. 
wers and L. spartea has consistent yellow flowers; on the other hand, the hybrid has a corolla of pale coloration, from yellowish to lilac. The L. spartea spur is vertical, while that of $L$. incarnata and the hybrid is oblique. L. spartea has bigger capsules than $L$. incarnata, and the hybrid plants have capsules that are intermediate in size. The hybrid inhabits grasslands in sandy soils, residing between its parents.

\section{References}

Aedo, C. 2013: Allium L. - Pp. 220-273 in: Rico, E., Crespo, M. B., Quintanar, A., Herrero, A. \& Aedo, C. (eds) Flora Iberica, 20. - Madrid.

Almeida, J. D. 2003: Adiciones corológicas a Flora iberica VII (I). - Bot. Complut. 27: 95-104.

Civis, J., Sierro, F. J., González Delgado, J. A., Flores, J. A., Andrés, L., de Porta, J. \& Valle, M. F. 1987: El Neógeno marino de la Provincia de Huelva: Antecedentes y definición de las unidades litoestratigráficas. - Pp. 9-23 in: Civis, J. (ed.) Paleontología del Neógeno de Huelva (SO Cuenca del Guadalquivir). - Salamanca.

García Martínez, X. R., Silva Pando, F. J., González Domínguez, J., Blanco Dios, J. B., Rodríguez González, A., Rial Pousa, S., Álvarez Graña, D., Camaño Portela, J. L., Pino Pérez, J. J. \& Pino Pérez, R. 2006: Aportaciones a la flora de Galicia, VIII. - Nova Acta Ci. Compostelana (Bioloxia) 15: 53-63

Garrido, P., Aparicio, A., Pérez Porras, C., Aparicio, J., García Martín, F., Fernández Carrillo, L. \& Carrasco, M.A. (2002) Flora de interés en bosques-isla de Andalucía Occidental. -Acta Bot. Malacitana 27: 295-308.

Magos, J. \& Kell, S. P. 2011: Allium pruinatum Link ex Spreng. The IUCN Red List of Threatened Species 2011. http://dx.doi.org/10.2305/IUCN.UK.2011-1.RLTS.T172160A6839854.en [Last Accessed 13/6/2019].

Morales, M., Delgado, J. M., Torrecilla, A., Tamajón, R. \& Muñoz, J. M. 1998: Novedades corológicas para la comarca de Sierra Norte en la provincia de Sevilla. - Lagascalia 20: 316-331.

Moreno, J. C. (coord. ) 2008: Lista Roja 2008 de la Flora Vascular Española. - Madrid.

Navarro, T. 2012: Teucrium L. - Pp. 30-166 in: Morales, R., Quintanar, A., Cabezas, F., Pujadas, A. J. \& Cirujano, S. (eds) Flora Iberica, 12. - Madrid.

Pastor, J. \& Valdés, B. 1983: Revisión del género Allium (Liliaceae) en la Península Ibérica e Islas Baleares. - Sevilla.

Pina, F. J. 2000: Novedades corológicas para la flora de Andalucía occidental. - Lagascalia 21: 349-351.

Podlech, D. 2000: Astragalus L. - Pp 279-338 in: Talavera, S., Aedo, C., Castroviejo S., Herrero, A., Romero Zarco, C., Salgueiro, F. J. \& Velayos, M. (eds) Flora Iberica, 7(2). - Madrid.

Pujadas, A. 1986: Flora arvense y ruderal de la Provincia de Córdoba. Tesis Doctoral Universidad de Córdoba. - Córdoba.

Rivas Goday, S. 1953: Especies indicadoras de los calerizos paleozoicos, en Extremadura. - Anales Inst. Bot. Cavanilles 11(1): 503-514.

Romero, T. 2009: Gratiola L. -Pp 324-328 in: Benedí, C., Rico, E., Güemes, J. \& Herrero, A. (eds) Flora Iberica, 13. - Madrid.

Sáez, L. \& Bernal, M. 2009: Linaria Mill. - Pp 232-324 in Benedí, C., Rico, E., Güemes, J. \& Herrero, A. (eds) Flora Iberica, 13. - Madrid.

Sánchez Gullón, E. 2000: Solanum sisymbrifolium Lam. (Solanaceae), nueva especie adventicia para la flora española. - Anales Jard. Bot. Madrid 57(2): 422-423. 
Sobrino Vesperinas, E. \& Sanz Elorza, M. 2012: Solanum L. - Pp 166-195 in: Talavera, S., Andrés, C., Arista, M., Fernández Piedra, M. P., Gallego, M. J., Ortiz, P. L., Romero Zarco, C., Salgueiro, F. J., Silvestre, S. \& Quintanar, A. (eds) Flora Iberica, 11. - Madrid..

Velayos, M. 1997: Lythrum L. - Pp 15-25 in: Castroviejo, S., Aedo, C., Benedí, C., Laínz, M., Muñoz Garmendia, F., Nieto Feliner, G. \& Paiva, J. (eds) Flora Iberica, 8. - Madrid.

Vicioso, C. 1948: Notas sobre la flora española. - Anales Jard. Bot. Madrid 6(2): 5-92.

Addresses of the authors:

Laura Sánchez Villegas ${ }^{1}$, Enrique Sánchez Gullón ${ }^{2}$ \& Adolfo Francisco Muñoz Rodríguez ${ }^{1}$,

${ }^{1}$ Dpto. Ciencias Integradas. Universidad de Huelva, Huelva 21071, España.

${ }^{2}$ Paraje Natural Marismas del Odiel (Huelva), Ctra. del Dique Juan Carlos I Km 3, Apdo., 720, E-21071 Huelva, España. Email: enrique.sanchez.gullon@juntadeandalucia.es 